Available online on 15.09.2016 at http://jddtonline.info
Journal of Drug Delivery and Therapeutics
An International Peer Reviewed Journal
Open access to Pharmaceutical and Medical research
(c) 2016, publisher and licensee JDDT, This is an Open Access article which permits unrestricted noncommercial use, provided the original
work is properly cited

\title{
ASSESSMENT OF KNOWLEDGE, ATTITUDE, AND PRACTICE OF SELF-MEDICATION AMONG HARAR HEALTH SCIENCES COLLEGE STUDENTS, HARAR, EASTERN ETHIOPIA
}

\author{
Weyni Hailemichael, Mekonnen Sisay*, Getnet Mengistu \\ School of Pharmacy, College of Health and Medical Sciences, Haramaya University, Harar, Ethiopia \\ Received 11 Aug 2016; Review Completed 30 Aug 2016; Accepted 30 Aug 2016, Available online 15 Sep 2016
}

\begin{abstract}
Background: Self-medication is the selection and use of non-prescription medicines by individuals' own initiatives to treat selfrecognized illnesses or symptoms. It is practiced significantly worldwide even though its type, extent and reasons for its practice may vary. No data is available on the current status of self-medication practices among students of Harar Health Science College (HHSC). Therefore, this study aimed to assess basic information on self-medication practices among students of HHSC, Harar, Ethiopia.

Methods: Institutional based cross sectional study was conducted on students in HHSC from March 21 to March 25, 2016. Study participants were determined by two step stratified sampling followed by simple random sampling techniques. Data was collected using self administered questionnaire prepared in English. Data was entered and analyzed using SPSS version 16. Cross tabulation, Pearson Chi-square $\left(\chi^{2}\right)$ test and logistic regression were applied to show the association between selected categorical variables with self medication. Data was then presented using tables, figures and charts.

Results: Out of the total 237 participants $112(36.50 \%)$ were males and 125(52.7\%) were females. The prevalence of the practice of self-medication was high (70\%) with most frequently reported problems being headache and mild pain (47.3) followed by GI problem $(30.8 \%)$ and eye and ear symptoms (29.1\%). Most of the respondents $(55.7 \%)$ read leaflet and $34.6 \%$ of the respondents had some knowledge about the definition of self-medication. The two main reasons for self-medication were knowledge gain $(37.6 \%)$ and time saving $(28.7 \%)$. Antibiotic $(47 \%)$ and pain killer $(37 \%)$ were the two most frequently consumed medications. Previous prescriptions (33.9\%) followed by Pharmacist/druggist (24.6\%) were the two most frequently reported source of drug information for self-medication in this study. Besides, $70 \%$ of the respondents agreed with the practice of self-medication in the present study. There were statistically significant differences between respondents who reported practicing self-medication based on study year $(\mathrm{p}<0.05)$. Most respondents had positive attitude towards self-medication and antibiotics were the drugs most commonly used for self-medication without a prescription despite the fact that they were aware of the risk of development of antimicrobial resistance.

Conclusion: The practice of self-medication was common and, in most cases, inappropriate. Most students had a positive attitude towards self-medication. Hence, drug authorities and health professionals need to educate students about the pros and cons of selfmedication.

Keywords: self medication, knowledge, attitude, practice
\end{abstract}

DOI: http://dx.doi.org/10.22270/jddt.v6i5.1329

URI: http://jddtonline.info/index.php/jddt/article/view/1329

\section{INTRODUCTION}

Self-medication can be defined as the use of drugs to treat self-diagnosed disorders or symptoms, or the intermittent or continued use of a prescribed drug for chronic or recurrent disease or symptoms. ${ }^{1}$ Self-care is what people do for their own selves to establish and maintain health, prevent and deal with illness. ${ }^{2}$ Studies revealed that increase in self-medication was due to a number of factors. These include socioeconomic factors, lifestyle, ready access to drugs, the increased potential to manage certain illnesses through self-care, and greater availability of medicinal products. ${ }^{3}$
Medicines for self-medication are often called 'nonprescription' or 'over the counter' (OTC) and are available without a doctor's prescription through pharmacies. In some countries OTC products are also available in supermarkets and other outlets. Medicines that require a doctor's prescription are called prescription products $\left(\mathrm{R}_{\mathrm{x}}\right.$ products). Self-medication with OTC medicines is sometimes referred to as 'responsible' self-medication to distinguish it from the practice of purchasing and using a prescription medicine without a doctors' prescription. Selfmedication is widely practiced in both developed and developing countries. Such medicines are normally used 
for the prevention or treatment of minor ailments or symptoms, which do not justify medical consultation. In some chronic or recurring illnesses, after initial diagnosis and prescription, self-medication is possible with the doctor retaining an advisory role. ${ }^{4,5}$

The main reasons for self-medication include health problem being not serious, the illness is minor, to get quick relief of the condition and to avoid long waiting at clinics. ${ }^{6,7}$

Inappropriate self-medication results in irrational use of drugs, wastage of resources, increased risk of adverse reactions and prolonged suffering. ${ }^{8}$ Irrational usage of antibiotics led to the emergence of resistance pathogens worldwide. ${ }^{9}$ Furthermore, The risk associated with selfmedications also include a potential of delay in treating a serious medical conditions, masking of symptom of the serious condition through the use of nonprescription products, increase polypharmacy and interaction with other regularly used medication. ${ }^{10}$

\section{METHODS}

\section{Study design and setting}

Institution based prospective cross-sectional study was conducted to assess the knowledge, attitude and practice of self-medication in HHSC students, Harar which is located $526 \mathrm{~km}$ from the capital of Ethiopia, Addis Ababa. The study was conducted from March 21-25, 2016.

\section{Study population}

Students in the department of Pharmacy, Public Health, Compressive Nursing and Midwifery of both genders and of any age during the academic year 2016 G.C were included. However, students who have reading, hearing and/or psychiatric problem as well as those who are not willing to participate in the study were excluded.

\section{Sample size determination and sampling techniques}

The sample size was determined by taking the following assumptions; since there was no previous study in the area, the estimated prevalence rate of population who practice and have positive agreement towards self-medication to be $50 \%$, with confidence level of $95 \%$, marginal error of $5 \%$ and non-response rate of $5 \%$.

$$
\mathrm{n}_{\mathrm{i}}=\frac{(\mathrm{Z} \alpha / 2) 2 \mathrm{P}(1-\mathrm{P})}{\mathrm{d} 2}=\frac{(1.96) 2 \times(0.5 \times 0.5)}{(0.05)^{2}}=384
$$

The study population $(\mathrm{N})$ was 546 students $(<10,000)$ and hence estimating the final sample size was done as follows

$$
\mathrm{n}_{\mathrm{f}}=\frac{n i}{n i+n i / N}
$$

where, $\mathrm{nf}=$ final sample size

ni=initial sample size

$\mathrm{N}=$ study population

$$
\mathrm{n}_{\mathrm{f}}=\frac{384}{(1+384 / 546)}=226 \text {. }
$$

With $5 \%$ non-response rate, $226+11=\mathbf{2 3 7}$ students were included in the study.

Two step stratified sampling (from college to departments and then to study years level) was employed based on appropriate proportion of the respective field of study. Finally, sample from each stratum (study year) was selected using simple random sampling.

\section{Data collection tools and procedures}

Structured questionnaire was prepared in English version. Data was collected using self administered questionnaire (filled by the respondent themselves).

\section{Data quality control}

The data was checked for completeness, accuracy, and those found missing in addressing important variables was discarded and no longer used as a predictor variable.

\section{Data processing and analysis}

Data was coded, given sequential numbers and entered into SPSS, version 16. Analysis was carried out using descriptive and inferential statistics. Cross tabulation, Pearson Chi-square test and logistic regression were applied for comparing the effects of selected categorical variables with self medication. $\mathrm{P}$ value less than 0.05 was considered to be statistically significant. The results were then presented in tables, figures and charts.

\section{Ethical consideration}

Approval and permission was sought from HHSC with letter written by School of Pharmacy, Haramaya University. To obtain the consent of college and students prior to data collection, a detailed explanation on the aim and objectives of the study was given.

\section{RESULT}

Out of the 237 participants, $112(47.3 \%)$ were males and $125(52.7 \%)$ were females. Most of the responding students $110(46.6 \%)$ were aged less than 20 years, $103(43.6 \%)$ were aged 20-24 and >24 were 23(9.7\%). Majority of the students were from Oromoia 107(45.1) followed by Amhara 67(28.1\%) and Harari 36 (15.2\%) regions. Most of the respondents were Orthodox 106(44.7\%) followed by Muslims 83(35\%). Besides, $151(63.7 \%)$ respondents live with their family. Coming to self medication practices, with in age category, percentage of drug bought or utilized seems to be increased as the age increases. However, there is no statistically significant association between age and self medication in this study (Table 1).

There is no statistically significant difference between the students' groups according to the use of selfmedication by their department (Pearson $\chi^{2}=7.09$, $\mathrm{p}=0.069$ ) In this study, from those who bought/used drugs previously, comprehensive nursing students accounted for $54(36.73 \%)$ followed by Pharmacy students $40(27.21 \%)$ (Figure 1). 
Table 1: Socio- demographic characteristics of students in relation to self medication practices in HHSC, Harar, Ethiopia, March 2016 (n=237)

\begin{tabular}{|c|c|c|c|c|c|}
\hline \multicolumn{2}{|c|}{ Socio demographic Variables } & Frequency $(\%)$ & Drug utilized without prescription & Pearson $\chi^{2}$ & $\mathrm{P}$ value \\
\hline \multirow[t]{3}{*}{ Age } & $<20$ & $110(46.6)$ & $64(58.2)$ & & \\
\hline & $20-24$ & $103(43.6)$ & $66(64.1)$ & & \\
\hline & $>24$ & $23(9.7)$ & $17(73.9)$ & 2.25 & 0.324 \\
\hline \multirow[t]{2}{*}{ Gender } & Male & $112(47.3)$ & $66(58.9)$ & & \\
\hline & Female & $125(52.7)$ & $81(64.8)$ & 0.07 & 0.791 \\
\hline \multirow[t]{5}{*}{ Ethnicity } & Oromia & $107(45.1)$ & $68(63.6)$ & & \\
\hline & Amhara & $67(28.1)$ & $39(58.2)$ & & \\
\hline & Tigray & $17(7.2)$ & $10(58.8)$ & & \\
\hline & Harari & $36(15.2)$ & $22(61.1)$ & & \\
\hline & Others & $10(4.2)$ & $8(80.0)$ & 1.98 & 0.74 \\
\hline \multirow[t]{4}{*}{ Religion } & Orthodox & $106(44.7)$ & $64(60.4)$ & & \\
\hline & Catholic & $22(9.3)$ & $12(54.5)$ & & \\
\hline & Muslim & $83(35)$ & $53(63.9)$ & & \\
\hline & Others & $26(11)$ & $18(69.2)$ & 1.37 & 0.71 \\
\hline \multirow{2}{*}{$\begin{array}{l}\text { Family } \\
\text { structure }\end{array}$} & Live with family & $151(63.7)$ & $91(60.3)$ & & \\
\hline & Live alone & $86(36.3)$ & $56(65.1)$ & 0.55 & 0.45 \\
\hline
\end{tabular}

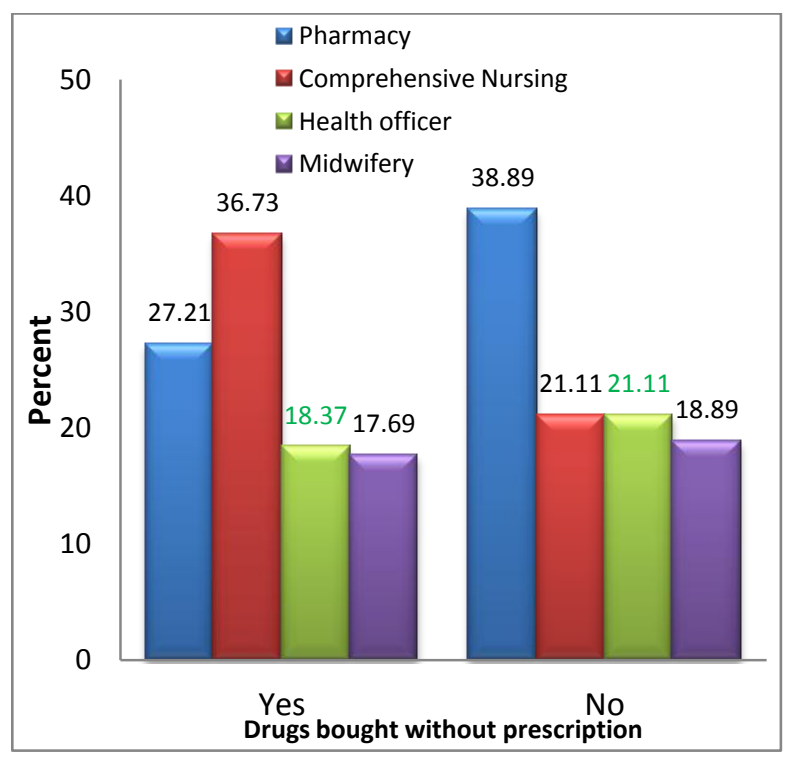

Figure 1: Departments of respondents who bought drug without prescription in HHSC, March, 2016 $(n=237)$
There have been statistically significant differences between the students' groups according to the use of self-medication by their study year (Pearson $\chi^{2}=34.78$, $\mathrm{p}<0.001)$. As study year is increased the prevalence of self-medication was increased. The study actually revealed the effects of knowledge gain on self medication practices as the year of enrollment increases. However, its positive effect might be overwhelmed by several negative factors such as emergence of drug resistance, adverse drug reactions (Table 2).

Fifty three $(22.4 \%)$ of the respondents had very good knowledge regarding self medication; $82(34.6 \%)$ had well; $77(32.5 \%)$ had poor and the rest $25(10.5 \%)$ had no knowledge about the definition of self-medication based on knowledge scaling. More than half $131(55.3 \%)$ of the respondents were aware of antimicrobial resistance (Table 3).

Table 2: Category of students who bought drugs without prescription by the study year in HHSC March, 2016 $(\mathrm{n}=237)$

\begin{tabular}{|l|l|l|r|r|}
\hline Study Year & \multicolumn{2}{|c|}{ Drug used or bought without prescription } & Pearson $\chi^{2}$ & P value \\
\hline First year & Yes & No & & \\
\hline Second year & $44(29.93)$ & $52(57.78)$ & & \\
\hline Third year & $49(33.33)$ & $34(37.78)$ & & \\
\hline Total & $54(38.78)$ & $4(4.44)$ & 34.78 & 0.00 \\
\hline
\end{tabular}


Table 3: Respondents' knowledge regarding self-medication in HHSC, Harar, Ethiopia, 2016 (n=237)

\begin{tabular}{|l|l|l|l|}
\hline Variables & Grading & Frequency & $\%$ \\
\hline \multirow{3}{*}{$\begin{array}{l}\text { Knowledge about definition of self- } \\
\text { medication }\end{array}$} & Very good & 53 & 22.4 \\
\cline { 2 - 4 } & Good & 82 & 34.6 \\
\cline { 2 - 4 } & poor & 77 & 32.5 \\
\cline { 2 - 4 } & Not at all & 25 & 10.5 \\
\hline \multirow{2}{*}{ Awareness of antimicrobial resistance } & Aware & 131 & 55.3 \\
\cline { 2 - 4 } & Nor aware & 106 & 44.7 \\
\hline
\end{tabular}

The majority $166(70 \%)$ of the respondents had a positive attitude towards self-medication and favored self-medication saying that they agreed, 51(21.5\%) disagreed, while $20(8.4 \%$ ) had no comment. Most of the respondents $114(48.1 \%)$ said that increase drug dose can be dangerous. Amongst the socio-demographic factors, religion has shown relationship with views on various aspects of self medication $(\mathrm{p}=0.004)$. Being an orthodox Christian is more likely to associate with views on some aspects self medication (Table 4).

Table 4: Respondents attitude regarding self-medication in HHSC, Harar, Ethiopia, 2016 ( $\mathrm{n}=237$ )

\begin{tabular}{|l|l|l|l|}
\hline Variables and scaling & Frequency & $\%$ \\
\hline \multirow{3}{*}{$\begin{array}{l}\text { Attitude towards self- } \\
\text { medication }\end{array}$} & Agreed & 166 & 70 \\
\cline { 2 - 4 } & Disagreed & 51 & 21.5 \\
\cline { 2 - 4 } & No comments & 20 & 8.4 \\
\hline \multirow{3}{*}{$\begin{array}{l}\text { Students views on of self- } \\
\text { medication }\end{array}$} & Increasing drug dose can be dangerous & 114 & 48.1 \\
\cline { 2 - 4 } & All medications have adverse effect & 44 & 18.6 \\
\cline { 2 - 4 } & No drug can be used during pregnancy & 36 & 15.2 \\
\cline { 2 - 3 } & Self-medication can mask signs and symptoms & 26 & 11 \\
\cline { 2 - 3 } & Decreasing drug dose can be dangerous & 17 & 7.2 \\
\hline
\end{tabular}

Of the 237 respondents, 147 (62\%) bought drug without prescription. Majority of the students $80(33.9 \%)$ obtained information about self-medications from previous prescription, $24.6 \%$ followed by pharmacists/druggists, $21.6 \%$. The most common health problems reported by respondents were headache and mild pain $47 \%$, GI problems $30.8 \%$, eye and ear infections, $29.1 \%$ among others. Most of the respondents $158(66.7 \%)$ took the same medication when presenting with similar symptoms. High number of students $135(57 \%)$ gave prescription to someone when have similar manifestations (Table 5).

Table 5: Self-medication practices of HHSC students, Harar, Ethiopia, $2016(n=237)$

\begin{tabular}{|c|c|c|c|}
\hline \multicolumn{2}{|l|}{ Self-medication practice Variables } & Frequency & $(\%)$ \\
\hline \multirow[t]{2}{*}{ Bought drug without prescription } & Yes & 147 & 62 \\
\hline & No & 90 & 38 \\
\hline \multirow[t]{5}{*}{ Source of self-medication information } & Previous prescription & 80 & 33.9 \\
\hline & Pharmacist & 58 & 24.6 \\
\hline & Study books /internet & 51 & 21.6 \\
\hline & Friends/ Family & 40 & 16.9 \\
\hline & Others & 7 & 3 \\
\hline \multirow[t]{5}{*}{ Common health problems } & Headache or mild pain & 112 & 47.3 \\
\hline & GI problems & 73 & 30.8 \\
\hline & Eye and ear symptoms & 26 & 29.1 \\
\hline & Vomiting & 15 & 6.3 \\
\hline & Others & 11 & 4.6 \\
\hline \multirow[t]{2}{*}{ Read the leaflets } & Yes & 132 & 55.7 \\
\hline & No & 105 & 44.3 \\
\hline \multirow{2}{*}{$\begin{array}{l}\text { The same medication used when presenting the same } \\
\text { symptoms }\end{array}$} & Yes & 158 & 66.7 \\
\hline & $\mathrm{No}$ & 79 & 33.3 \\
\hline \multirow{2}{*}{$\begin{array}{l}\text { Gave prescription to someone who have similar } \\
\text { symptoms }\end{array}$} & Yes & 135 & 57.0 \\
\hline & No & 102 & 43.0 \\
\hline
\end{tabular}

Self medication practices might be emanated from variety of reasons in this study, $37 \%$ of students' reason to selfmedicate was knowledge gain followed by $29 \%$ time saving (Figure 2). 


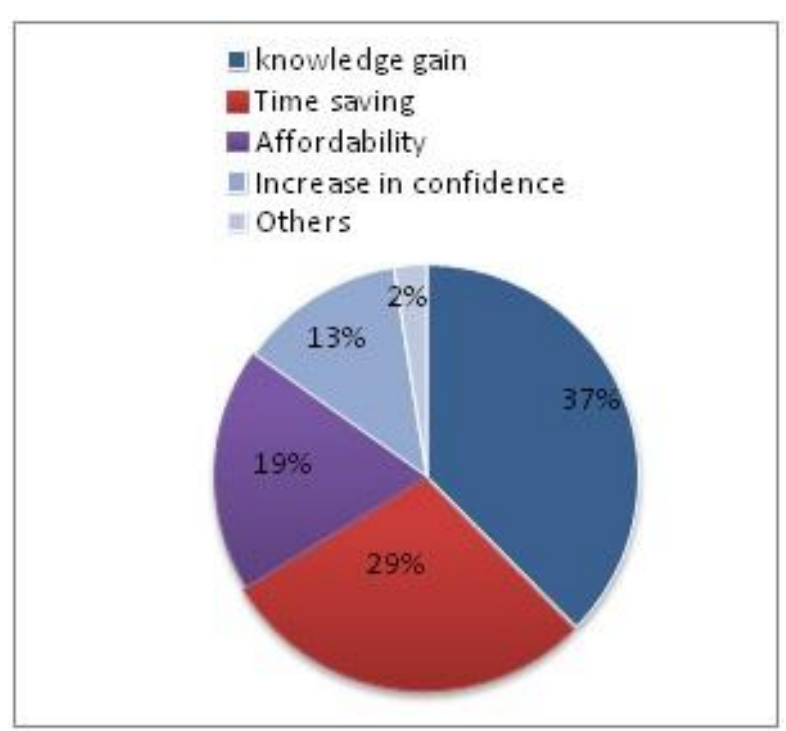

Figure 2: The reasons for self-medication given by respondents in HHSC, $2016(n=237)$

Besides, the most common types of self-medication used by participants include antibiotic (47\%), pain killer (37\%), vitamins and minerals (10\%) among others (Figure 3).

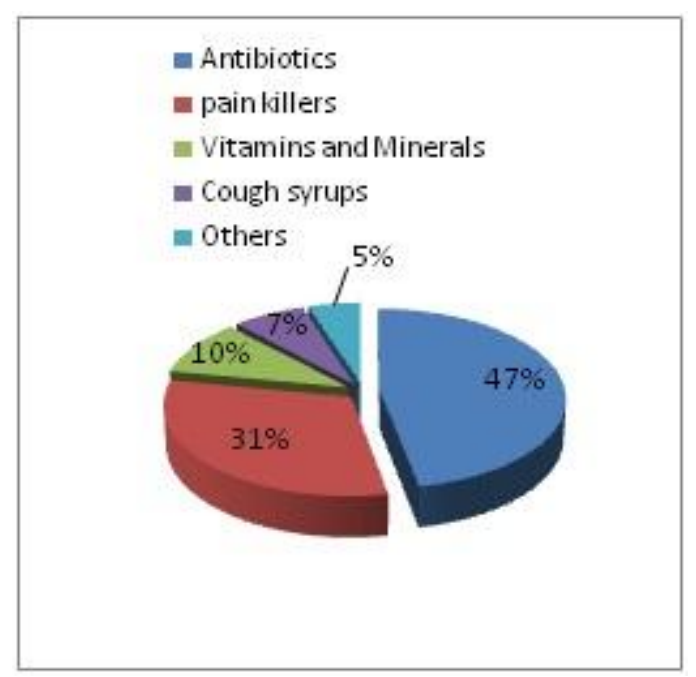

Figure 3: Commonly used self-medications among HHSC students, Harar, Ethiopia, 2016 (n=237)

\section{DISCUSSION}

Self-medication is the practice whereby individuals treat their ailments and conditions with medicines which are approved and available without prescription, and which are safe and effective when used as directed. However, it will lead to unintended effect if inappropriately used. ${ }^{10}$

Studies revealed that increase in self-medication was due to a number of factors. These include socioeconomic factors, lifestyle changes, ready access to drugs, the increased potential to manage certain illnesses through self-care, and greater availability of medicinal products. ${ }^{3}$
The issue of long waiting queues at clinics or hospitals was also raised by the respondents as one of the reasons for seeking self-care in order to meet up with their tight lecture schedule. Respondents used selfprescribed drugs to treat their self-diagnosed disorders or ailments based on their own initiative. ${ }^{11}$

Concerning the socio-demographic characteristics, most of the respondents were females $(52.7 \%)$, less than 20 years old $(46.6 \%)$, those came from Oromia region $(45.1 \%)$, Follower of orthodox $(44.7 \%)$, and live with their family $(63.7 \%)$.

In this study, the prevalence of self-medication (62\%) among the study subjects was higher than the study done in Mekelle University (43.24\%) ${ }^{12}$ and Gondar University $38.20 \%^{13}$. Most important reason for higher trend of self-medication might be the easy availability of medicines without prescription.

There had been statistically significant differences between the students' groups according to the use of self-medication by their study year $(\mathrm{p}<0.05)$. As study year is increased the prevalence of self-medication was increased. This may partially attributable to knowledge gain to treat themselves despite the negative impacts of self medication such as emergence of adverse drug reactions, antimicrobial resistance and drug-drug interactions.

The prevalence of self-medication amongst university students in Palestine was found to be about $98 \% .^{14}$ regarding the knowledge on definition of selfmedication, $34.6 \%$ of the respondent had some knowledge on this study. This shows that most of the subjects had shortage of knowledge in the definition of self-medication and this can result to improper usage.

Concerning the source of information about selfmedication, (33.9\%) respondent in study use previous prescription the study done in Pakistan showed that (23.8\%) respondent used previous history same medication. This is may be due to lack of awareness as using previous experience may be exposed to the dangers of misdiagnosis and consequently wrong treatment.

In this study the most common reason for selfmedication reported by a large number $(37.6 \%)$ of participants was due to increases the knowledge regarding drugs and their use which is similar reason with the study done in Mekelle university. ${ }^{12}$ However, affordability was a majorly reason reported in other study conducted in Jimma town $(35.70 \%)^{15}$ and in a study from Tamil Nadu most students practiced selfmedication as it was time saving. ${ }^{1}$

The most common types of health problem faced for which the respondents reported were headache and mild pain $(47 \%)$ which shows lower value compared to the study done in Mekelle university $(51.56 \%){ }^{12}$

Alarmingly, $47 \%$ of the respondents obtained antibiotics for self-medication without a prescription despite the fact that they were aware of the risk of development of bacterial resistance in $55.3 \%$ students. This is similar to the results reported from Nepal. ${ }^{4}$ This 
might be due to high access of these medication and poor usage of antimicrobials.

The majority $(70 \%)$ of the respondents had a positive attitude towards self-medication and favored selfmedication saying that they agreed. This was comparable with the study done in Jimma university ${ }^{10}$ but relatively high as compared to the report from Gonder University which is $55.5 \%{ }^{13}$ and study in Mekelle University $(52.30 \%) .{ }^{12}$ This might be a means for drug interaction with regular medicine, drug resistance for antimicrobials, masking and complication of illnesses and increase irrational use of medicines.

\section{CONCLUSION}

The practice of self-medication was common and, in most cases, inappropriate. Most Students had a positive attitude towards self-medication and antibiotics were the drugs most commonly used for self-medication without a prescription despite the fact that majority of them were aware of the risk of emergence of antimicrobial resistance. Many diseases have similar symptoms, and a person using previous experience may be exposed to the dangers of misdiagnosis and consequently wrong treatment.

\section{Acknowledgements}

We would like to thank Haramaya University for provision of material supports. We also extend our deep appreciation for Harar Health Sciences College staffs and students for their kindly support.

\section{Competing interests:}

The authors have declared that there is no competing interest

\section{Authors' Contribution}

WH and MS were involved in conception of the original idea, helped to draft the proposal, participated in all implementation stages of the project, and write up; all authors including GM reviewed it critically and involved preparation of the manuscript. All authors read and approved the final version of the manuscript.

\section{Funding: None}

\section{REFERENCES}

1. Badiger S. Kundapur R, Jain A, Kumar A, et al, Selfmedication Patterns among medical students in South India, Australasian Medical Journal 2012;5(4):217-20

2. World Health Organization (WHO): Role of pharmacists in self-care and self-medication. The Fourth consultative group meetings on the role of the pharmacist in the health care system organized by WHO in collaboration with the International Pharmaceutical Federation (FIP), Hague 1998, pp. 2-11.

3. World Health Organization. The Role of pharmacist in Heath Care System; 1998. available from: http://www.apps.who.int /medicinedocs/en/d/Jwhozip32e last accessed on Nov 2015

4. Shankar PR, Partha P, Shenoy N: Self-medication and nondoctor prescription practices in Pokhara valley, Western Nepal: a questionnaire-based study. BMC Family Practice 2002, 3:17.

5. Mohammed A and Ales K, Self-medication with antibiotics by the community of Abu Dhabi Emirate, United Arab Emirates. J. Infect. Dev. Ctrie 2009 3: 491-497

6. Olayemi, O.J., B.O. Olayinka and A.I. Musa, Evaluation of antibiotic self-medication pattern Amongst undergraduate students of Ahmadu Bello university (main campus), Zaria. Res. J. Applied Sci. Eng. Technol.2010, 2: 35-38.

7. Sontakke SD, Bajait CS, Pimpalkhute SA et al Comparative study of evaluation of self-medication practices in first and third year medical students. Int. J. Biol. Med. Res.2011, 2: 561-564

8. Kiyingi KS, Lauwo JA; Drugs in the home: Danger and waste. World Health Forum, 1993; 14: 381-384.

9. Pagane D, Self-medication and health insurance coverage in Mexico. Health Policy 2007; 75(2): 170-177.

10. Angamo and Wabe, Evaluation of the Knowledge, Attitude and practice of self- Medication among undergraduate medical students IJPSR 2012, 3:1005-1010

11. Osemene KP and Lamikanra A, the Prevalence of SelfMedication Practice among University Students in Southwestern Nigeria Tropical Journal of Pharmaceutical Research 2012; 11 ;683-689

12. Gutema A: Self-Medication Practices among Health Sciences Students: The Case of Mekelle University, Journal of Applied Pharmaceutical Science 201, 01 : 183-189

13. Abay SN, Amelo W, Assessment of Self-Medication Practices Among Medical, Pharmacy, and Health Science Students in Gondar University, Ethiopia. Journal of young and Pharmacy, 2010, 2: 306-310.

14. Sawalha AF; Assessment of self-medication practice among University students in Palestine: Therapeutic and Toxicity Implications. The Islamic University Journal (Series of Natural Studies and Engineering)2007 15(2):67-82

15. G/Mariam A, Worku S: Practice of self-medication in Jimma town. Ethiop. J. Health Dev.2003; 17:111-11

*Corresponding Author: Mekonnen Sisay (mekonnensisay27@yahoo.com), Department of Pharmacology, School of Pharmacy, College of Health and Medical Sciences, Haramaya University, Harar, P.O. Box 125, Ethiopia, Cell phone, +251920-21-21-35 